\title{
UPAYA MENINGKATKAN HASIL BELAJAR MATEMATIKA KELAS III DENGAN MODEL DISCOVERY LEARNING PADA MASA PANDEMI COVID-19
}

\section{Sri Haryati Rahayuningsih* \& Nani Mediatati}

Program Studi Pendidikan Profesi Guru Sekolah Dasar, Fakultas Keguruan dan Ilmu Pendidikan, Universitas Kristen Satya Wacana. Jalan Diponegoro No. 52-60, 50711, Indonesia. Email : 952020524@student.uksw.edu

\section{Article History}

Received : April $28^{\text {th }}, 2021$

Revised : May 04 ${ }^{\text {th }}, 2021$

Accepted : May $10^{\text {th }}, 2021$

Published : May $18^{\text {th }}, 2021$

\begin{abstract}
Abstrak: Penelitian ini dilatarbelakangi oleh pengamatan pembelajaran di kelas 3 SDN Bumireso Kec. Wonosobo Kab. Wonosobo dengan rata-rata nilai matematika peserta didik kurang dari KKM yang ditetapkan untuk matematika yaitu 70 . Hanya $34 \%$ dari jumlah peserta didik yang sudah memenuhi nilai KKM dan $66 \%$ masih belum memenuhi nilai KKM. Tujuan penelitian ini adalah untuk meningkatkan hasil belajar matematika melalui model Discovery Learning pada peserta didik kelas 3 SD Negeri Bumireso. Penerapan model pembelajaran ini mencakup 6 langkah pembelajaran yaitu stimulus (stimulation), identifikasi masalah (problem statement), pengumpulan data (data collecting), pengolahan data (data processing), verifikasi (verification), generalisasi (generalization). Jenis penelitian merupakan penelitian tindakan kelas (PTK). Penelitian dilaksanakan 2 siklus pada bulan Maret 2021 dengan subjek penelitian peserta didik kelas 3 SD Negeri Bumireso sebanyak 29 siswa. Teknik pengumpulan data menggunakan tes dan teknik analisis data dengan teknik deskriptif kuantitatif. Hasil penelitian menunjukkan bahwa melalui penerapan model Discovery Learning dapat meningkatkan hasil belajar matematika peserta didik kelas 3 SD Negeri Bumireso. Hal tersebut dibuktikan dengan data meningkatnya rata-rata hasil belajar peserta didik dari kondisi awal (pra siklus) yaitu 65 dengan tingkat ketuntasan hasil belajar sebesar 34\%, menjadi 78 dengan tingkat ketuntasan hasil belajar sebesar $69 \%$ pada siklus I, dan menjadi 84 dengan tingkat ketuntasan hasil belajar sebesar $83 \%$ pada siklus II
\end{abstract}

Kata Kunci: Hasil Belajar Matematika, Discovery Learning

\section{PENDAHULUAN}

Seluruh belahan bumi sedang waspada dengan corona virus yang sering disebut covid19. Covid-19 menimbulkan penyakit mulai dari flu hingga dapat menimbulkan kematian. Seiring dengan adanya penyebaran virus covid-19 ini di berbagai belahan dunia, tidak terkecuali Indonesia juga terdampak wabah covid-19 hampir di semua provinsi. Wabah ini menyebabkan banyak sektor yang mengalami pembatasan seperti sektor industri, sektor transportasi, sektor ekonomi, sektor pemerintahan dan bahkan sampai sektor pendidikan. Dalam sektor pendidikan berimbas pada pembatasan pembelajaran tatap muka karena dianggap bisa menjadi sarana penyebaran virus corona. Dengan pembatasan pembelajaran tatap muka, maka pemerintah mengambil tindakan dengan menggagaskan sistem pembelajaran jarak jauh. Pada sistem pembelajaran jarak jauh guru dan peserta didik hanya berkomunikasi via alat komunikasi seperti HP/ smartphone atau PC/ laptop. Dengan dibantu berbagai aplikasi maka guru dan peserta didik diharapkan dapat melaksanakan pembelajaran walaupun tidak dengan tatap muka secara langsung. Hal ini dilakukan agar guru dan peserta didik tetap dapat melaksanakan pembelajaran tanpa adanya rasa khawatir akan tertular penyakit covid-19. Dengan adanya sistem pembelajaran ini tentu pola belajar peserta didik akan berubah, peserta didik akan melaksanakan pembelajaran dari tempat tinggal peserta didik itu sendiri bukan di sekolah. 
Pengamatan yang dilakukan terhadap pembelajaran di kelas 3 Sekolah Dasar Negeri (SDN) Bumireso Kec. Wonosobo Kab. Wonosobo menunjukkan bahwa pada awalnya peserta didik antusias dalam pembelajaran jarak jauh, tetapi semakin lama antusiasme peserta didik berkurang. Peserta didik tidak mengerjakan tugas dan tidak mengumpulkan tugas sesuai dengan waktu yang ditentukan. Selain itu ratarata nilai matematika peserta didik masih kurang dari KKM yang ditetapkan untuk matematika yaitu 70. Nilai yang diperoleh 19 peserta didik dilihat dari nilai tes formatif $<70$ yang berarti peserta didik belum mencapai KKM dan hanya 10 peserta didik yang nilainya telah mencapai $\mathrm{KKM} \geq 70$. Data tersebut menunjukkan bahwa hanya $34 \%$ dari jumlah peserta didik yang sudah memenuhi nilai KKM dan $66 \%$ masih belum memenuhi nilai KKM.

Kondisi demikian apabila terus dibiarkan berlarut-larut tanpa adanya tindakan untuk mengubah atau memperbaikinya dikhawatirkan akan berdampak buruk terhadap kualitas pembelajaran di kelas 3 pada khususnya, dan di SDN Bumireso secara keseluruhan. Untuk meningkatkan hasil belajar peserta didik maka guru harus mengelola kegiatan pembelajaran yang dapat meningkatkan motivasi peserta didik dalam mengikuti kegiatan pembelajaran secara jarak jauh dan dapat dilakukan mandiri di rumah. Salah satu model pembelajaran yang menuntut keaktifan peserta didik dan dapat dilakukan secara mandiri di rumah adalah melalui Discovery Learning. Hosnan (2016: 85), menyatakan "pembelajaran Discovery Learning adalah suatu model pembelajaran yang dapat mengembangkan cara belajar peserta didik aktif dengan menemukan sendiri, menyelediki sendiri, maka hasil yang akan diperoleh peserta didik dapat bertahan lama dalam ingatan, tidak akan mudah dilupakan oleh peserta didik". Melalui cara belajar menemukan, peserta didik akan dapat berpikir analisis dengan menemukan sendiri jawaban dari permasalahan yang dihadapinya. Pendapat lain diungkapkan oleh Muhammad (dalam Hosnan, 2016: 51), yang berpendapat bahwa Discovery Learning adalah suatu proses dalam belajar yang di dalamnya dipaparkan konsep dalam bentuk jadi, namun peserta didik dituntut untuk mengorganisasi sendiri cara belajarnya dalam menemukan konsepnya.
Proses belajar peserta didik dikatakan berhasil atau tidak, tercermin dari hasil usaha yang dilakukan selama proses belajar berlangsung melalui suatu evaluasi belajar. Hasil belajar peserta didik digunakan sebagai patokan untuk melihat penguasaan belajar setelah diadakannya kegiatan pembelajaran. Hasil belajar yang menjadi objek penilaian kelas berupa kemampuan-kemampuan baru yang diperoleh peserta didik setelah mengikuti proses belajar mengajar tentang mata pelajaran tertentu. Pemerolehan kemampuan tersebut akan terwujud dalam perubahan tingkah laku tertentu, seperti dari tidak tahu menjadi tahu tentang sesuatu, dari acuh tak acuh menjadi menyukai objek dan aktivitas tertentu, serta dari tidak bisa menjadi cakap dalam melakukan keterampilan tertentu (Supratiknya, 2012: 5). Hasil belajar adalah perubahan tingkah laku yang ditunjukkan peserta didik setelah ia memperoleh pengalaman belajar dalam ranah kognitif, afektif, maupun psikomotor. Dalam penelitian ini hasil belajar yang diteliti adalah hasil belajar kognitif matematika.

Beberapa hasil penelitian terdahulu menunjukkan adanya peningkatan hasil belajar siswa melalui penerapan model pembelajaran Discovery Learning. Pertama, Oktaviani dkk (2018) yang melakukan penelitian di SD Negeri 3 Nambuhan, Kecamatan Purwodadi, Kabupaten Grobogan menunjukkan bahwa hasil belajar siswa meningkat dilihat dari tingkat ketuntasan siswa pada pra siklus sebesar $34,61 \%$, pada siklus I sebesar 73,07\%, dan siklus II meningkat sebesar $84,62 \%$. Kedua, Prasasti dkk (2019) melakukan penelitian di kelas IV SD Negeri Tegalrejo 02 Salatiga dengan jumlah siswa sebanyak 26 siswa menunjukkan bahwa hasil belajar siswa pada pra siklus hanya $35 \%$ meningkat pada siklus I menjadi $77 \%$, kemudian meningkat lagi menjadi $85 \%$ pada siklus II.

Penelitian ini dilakukan dengan tujuan untuk : (1) mendeskripsikan langkah-langkah penerapan model Discovery Learning dalam meningkatkan hasil belajar matematika peserta didik kelas 3 SDN Bumireso pada masa pandemic covid-19, (2) mengetahui peningkatan hasil belajar matematika peserta didik kelas 3 SDN Bumireso setelah diterapkan model Discovery Learning.

Berdasarkan tujuan penelitian maka disusun hipotesis tindakan yaitu melalui penerapan langkah-langkah pembelajaran pada model Discovery Learning yang meliputi stimulus (stimulation), identifikasi masalah (problem statement), pengumpulan data (data 
collecting), pengolahan data (data processing), verifikasi (verification), generalisasi (generalization) dapat meningkatkan hasil belajar matematika peserta didik kelas 3 SDN Bumireso pada masa pandemic covid- 19 .

\section{METODE}

Subjek dari penelitian tindakan kelas ini adalah peserta didik Kelas 3 SDN Bumireso semester II tahun pelajaran 2020/2021. Karakteristik peserta didik Kelas 3 ini adalah berumur antara 8 tahun sampai 11 tahun dengan jumlah 29 peserta didik yang terdiri dari 11 peserta didik perempuan dan 18 peserta didik laki-laki. Seluruh peserta didik belum mempunyai gawai sendiri, peserta didik menggunakan gawai orang tua untuk belajar jarak jauh dengan pendampingan orang tua. Mayoritas pekerjaan orang tuanya adalah sebagai pedagang yang tetap bekerja selama pandemi. Orang tua peserta didik rata-rata bekerja dari pagi hingga sore dan membawa gawai tersebut.

Jenis penelitian adalah Penelitian Tindakan Kelas (PTK) yang dilaksanakan dalam dua siklus di mana setiap siklus terdiri atas dua kali pertemuan. Kegiatan dalam setiap siklus mengacu pada konsep pokok penelitian tindakan menurut Arikunto (2011: 16) meliputi empat tahap yaitu menyusun rancangan tindakan atau perencanaan (planning), pelaksanaan tindakan (acting), observasi (observing), dan refleksi (reflecting). Variabel penelitian terdiri dari variabel bebas yaitu pembelajaran dengan model discovery learning dan variabel terikatnya adalah hasil belajar matematika peserta didik.

Teknik pengumpulan data menggunakan tes dengan instrumen berupa lembar soal tes isian singkat yang diberikan untuk mengukur tingkat pemahaman matematika peserta didik yang dinilai dengan satuan angka. Analisis yang digunakan untuk menguji keabsahan dan kevalidan butir soal tes adalah uji validitas dan uji reliabilitas dengan menggunakan program SPSS Versi 23.

Penerapan model discovery learning dalam pembelajaran jarak jauh ini diharapkan dapat mendorong peserta didik membangun konsep secara mandiri, aktif belajar dengan menemukan sendiri, serta menyelediki sendiri, sehingga hasil belajar peserta didik dapat meningkat karena pemahaman peserta didik bertahan lama dalam ingatan dan tidak akan mudah dilupakan.
Indikator keberhasilan dalam penelitian ini apabila jumlah peserta didik yang mencapai $\mathrm{KKM} \geq 70$ (tuntas) sebanyak $\geq 80 \%$ dari seluruh peserta didik kelas 3 SD Negeri Bumireso. Teknik analisis data yang digunakan adalah teknik analisis deskriptif kuantitatif dengan menggunakan persentase yaitu membandingkan hasil belajar matematika berdasarkan ketuntasan hasil belajar matematika antara prasiklus, siklus I, dan siklus II.

\section{HASIL DAN PEMBAHASAN}

Peneliti dilakukan dalam dua siklus. Setiap siklus terdiri dari dua kali pertemuan dengan alokasi waktu 3 x 30 menit. Kegiatan pembelajaran pada siklus I secara garis besar sesuai dengan model discovery learning. Pertemuan pertama guru menginformasikan kepada wali peserta didik untuk hadir ke sekolah untuk mengumpulkan tugas sebelumnya serta mengambil LKPD dan evaluasi pembelajaran tema 7 menentukan luas dengan satuan tidak baku. Setelah itu guru menjelaskan kepada wali peserta didik kegiatan dan tugas yang harus dilakukan siswa saat belajar di rumah. Pembelajaran jarak jauh luring sesuai dengan model discovery learning diawali dengan peserta didik diberi stimulus atau rangsangan yang berupa gambar dan cerita tentang halaman rumah Paman Budi yang akan dihias dengan rumput gajah mini. Peserta didik melakukan identifikasi masalah dengan mendapatkan pertanyaan pada LKPD yang harus dipecahkan yaitu bagaimana mengukur rumput yang dibutuhkan untuk menghiasi halaman rumah jika tidak memiliki alat ukur baku. Kemudian peseta didik melakukan pengumpulan data (data collection) dengan diberi kesempatan untuk menjawab pertanyaan tentang menentukan luas dengan satuan tidak baku, melakukan pengolahan data (data processing) dengan menyusun jawaban berdasarkan sumber yang ada di rumah dan menuliskan hasil jawabannya. Setelah itu, peserta didik melakukan pembuktian (verification) dengan membuktikan benar atau tidaknya hipotesis yang sudah ditetapkan dengan temuan siswa dari data processing. Langkah terakhir siswa menyimpulkan hasil jawabannya. Pada pertemuan kedua peserta didik mengerjakan evaluasi yang telah diberikan guru kepada wali peserta didik pada pertemuan pertama. Setelah itu wali peserta didik mengumpulkan LKPD dan lembar evaluasi ke sekolah. Guru menganalisis LKPD dan evaluasi 
peserta didik. Pada siklus I tidak ada kendala, namun karena belum mencapai indikator keberhasilan yang ditargetkan penulis maka guru melanjutkan tahap siklus kedua.

Kegiatan pada siklus II secara garis besar sesuai dengan model discovery learning pada siklus I namun berbeda materi yang diajarkan. Pertemuan pertama guru menginformasikan kepada wali peserta didik untuk hadir ke sekolah untuk mengumpulkan tugas sebelumnya serta mengambil LKPD dan evaluasi pembelajaran tema 7 menentukan luas dengan satuan tidak baku. Setelah itu guru menjelaskan kepada wali peserta didik kegiatan dan tugas yang harus dilakukan siswa saat belajar di rumah. Pembelajaran jarak jauh luring sesuai dengan model discovery learning diawali dengan peserta didik diberi stimulus atau rangsangan yang berupa gambar dan cerita tentang taman Paman Budi yang akan dicat. Peserta didik melakukan identifikasi masalah dengan mendapatkan pertanyaan pada LKPD yang harus dipecahkan yaitu bagaimana mengukur luas taman yang dicat jika tidak memiliki alat ukur baku. Kemudian peserta didik melakukan pengumpulan data (data collection) dengan diberi kesempatan untuk menjawab pertanyaan tentang menentukan luas dengan satuan tidak baku, melakukan pengolahan data (data processing) dengan menyusun jawaban berdasarkan sumber yang ada di rumah dan menuliskan hasil jawabannya. Setelah itu, peserta didik melakukan pembuktian (verification) dengan membuktikan benar atau tidaknya hipotesis yang sudah ditetapkan dengan temuan siswa dari data processing. Langkah terakhir siswa menyimpulkan hasil jawabannya. Pada pertemuan kedua peserta didik mengerjakan evaluasi yang telah diberikan guru kepada wali peserta didik pada pertemuan pertama. Setelah itu wali peserta didik mengumpulkan LKPD dan lembar evaluasi ke sekolah. Guru menganalisis LKPD dan evaluasi peserta didik. Pada siklus II tidak ada kendala dan telah mencapai indikator keberhasilan yang ditargetkan dalam penelitian ini, sehingga guru tidak melanjutkan ke siklus berikutnya.

Untuk mengetahui peningkatan hasil belajar matematika peserta didik kelas 3 SDN Bumireso, maka disajikan dalam tabel berikut ini perbandingan ketuntasan hasil belajar antara kondisi awal (pra siklus), siklus I, dan siklus II.

\section{Tabel 1. Perbandingan Ketuntasan Hasil Belajar Pada Kondisi Awal, Siklus I, dan Siklus II}

\begin{tabular}{ccccccccc}
\hline No. & $\begin{array}{c}\text { Ketun } \\
\text { tasan } \\
\text { Belajar }\end{array}$ & Nilai & \multicolumn{2}{c}{$\begin{array}{c}\text { Pra } \\
\text { siklus }\end{array}$} & $\begin{array}{c}\text { Siklus } \\
\text { I }\end{array}$ & $\begin{array}{c}\text { Siklus } \\
\text { II }\end{array}$ \\
\cline { 3 - 8 } & $\sum$ & $\%$ & $\sum$ & $\%$ & $\sum$ & $\%$ \\
\hline 1. & $\begin{array}{c}\text { Tidak } \\
\text { tuntas }\end{array}$ & $<70$ & 19 & 66 & 9 & 31 & 5 & 17 \\
\hline 2. & Tuntas & $\geq 70$ & 10 & 34 & 20 & 69 & 24 & 83 \\
\hline & Jumlah & 29 & & 29 & & 29 & \\
\hline & Nilai Rata-rata & 65 & & 78 & 84 \\
\hline & Nilai Tertinggi & 100 & 100 & 100 \\
\hline Nilai Terendah & 0 & & 0 & 0 \\
\hline
\end{tabular}

Berdasarkan tabel 1 nilai rata-rata hasil belajar mengalami peningkatan tiap siklus, pada kondisi awal nilai rata-rata hasil belajar sebesar 65, pada siklus I nilai rata-rata hasil belajar sebesar 78, dan pada siklus II nilai rata-rata hasil belajar sebesar 84 . Peningkatan rata-rata hasil belajar tiap siklus dapat disajikan pada diagram 1 berikut.

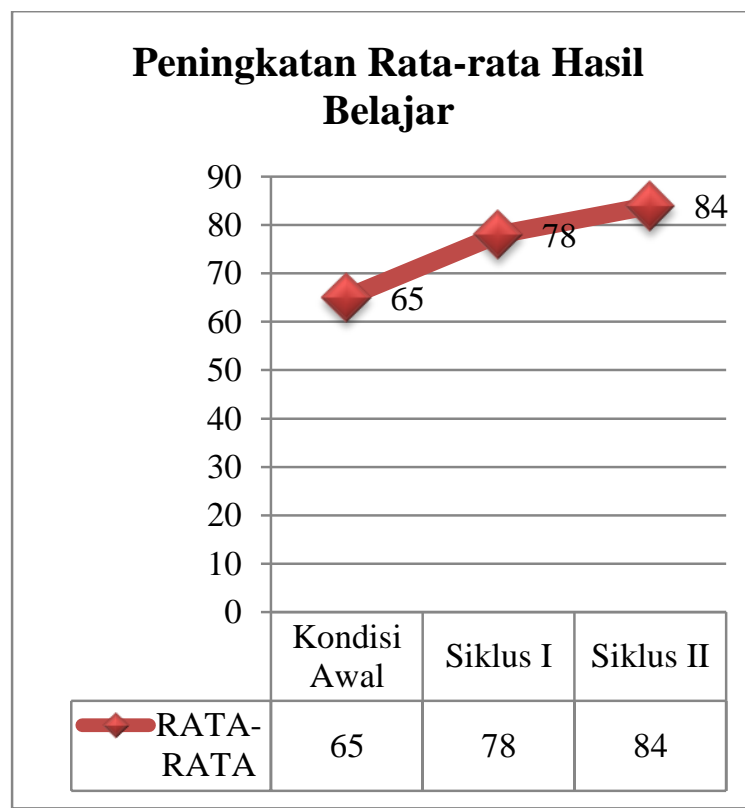

Diagram 1. Peningkatan Rata-Rata Hasil Belajar Pada Kondisi Awal, Siklus I, dan Siklus II

Berdasarkan tabel 1, juga menunjukkan pencapaian ketuntasan hasil belajar mengalami peningkatan pada tiap siklus. Pada kondisi awal yang tidak tuntas hasil belajarnya sebanyak 19 peserta didik atau 66\% dari 29 peserta didik dan yang tuntas hasil belajarnya sebanyak 10 peserta 
didik atau 34\% dari 29 peserta didik. Pada siklus I yang tidak tuntas hasil belajarnya sebanyak 9 peserta didik atau $31 \%$ dari 29 peserta didik dan yang tuntas hasil belajarnya sebanyak 20 peserta didik atau $69 \%$ dari 29 peserta didik, sedangkan pada siklus II yang tidak tuntas hasil belajarnya sebanyak 5 peserta didik atau 17\% dari 29 peserta didik dan yang tuntas hasil belajarnya sebanyak 24 peserta didik atau $83 \%$ dari 29 peserta didik. Perbandingan ketuntasan hasil belajar tiap siklus dapat disajikan pada diagram 2 berikut.

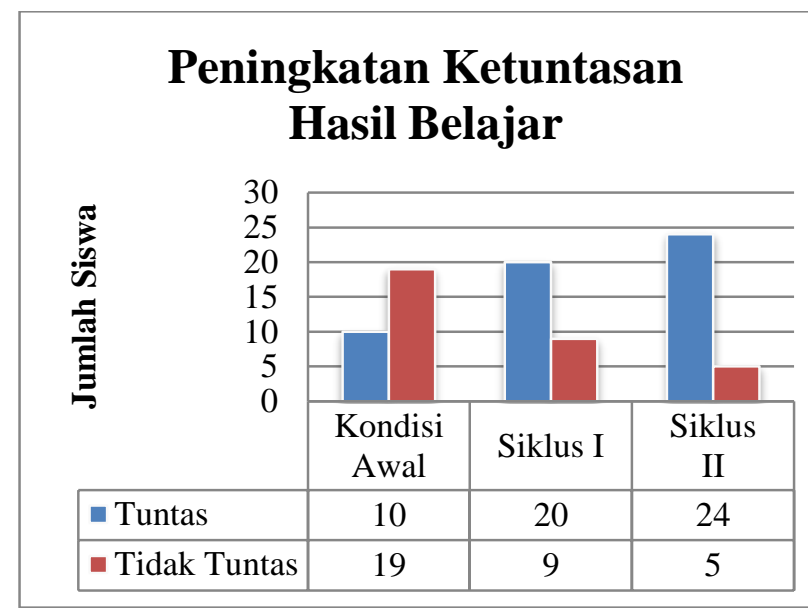

Diagram 2. Peningkatan Ketuntasan Hasil Belajar Pada Kondisi Awal, Siklus I, dan Siklus II

Dari data hasil belajar matematika peserta didik yang meningkat pada siklus II dapat dinyatakan bahwa pembelajaran jarak jauh tipe luring dengan menggunakan model discovery learning dapat meningkatkan hasil belajar peserta didik. Penelitian tindakan kelas yang dilaksanakan telah berhasil dan telah mencapai indikator keberhasilan penelitian yaitu ketuntasan hasil belajar peserta didik mencapai $\geq 80 \%$ dari 29 peserta didik kelas 3 SDN Bumireso dengan $\mathrm{KKM} \geq 70$, di mana pada siklus II terdapat 24 peserta didik atau $83 \%$ dari 29 peserta didik telah tuntas hasil belajarnya dan terdapat 5 peserta didik atau $17 \%$ dari 29 peserta didik yang tidak tuntas hasil belajarnya. Dengan demikian indikator keberhasilan penelitian yang ditentukan telah tercapai setelah implementasi pembelajaran pada siklus II.

\section{KESIMPULAN}

Berdasarkan hasil penelitian yang telah dilaksanakan maka dapat ditarik kesimpulan bahwa: melalui penerapan langkah-langkah pembelajaran model Discovery Learning yang meliputi stimulus (stimulation), identifikasi masalah (problem statement), pengumpulan data (data collecting), pengolahan data (data processing), verifikasi (verification), generalisasi (generalization) dapat meningkatkan hasil belajar matematika peserta didik kelas 3 SDN Bumireso pada masa pandemi covid-19 ini. Hal itu terbukti dengan data pada saat kondisi awal atau pra siklus rata-rata hasil belajar matematika peserta didik adalah 65 dengan skor tertinggi 100 dan skor terendah 0. Peserta didik yang tuntas KKM hanya $34 \%$. Setelah diterapkan model Discovery Learning rata-rata hasil belajar matematika peserta didik mengalami peningkatan pada siklus I menjadi 78 dengan nilai tertinggi 100 dan nilai terendah 0 , dan peserta didik yang tuntas KKM menjadi $69 \%$. Selanjutnya pada siklus II rata-rata hasil belajar matematika peserta didik meningkat menjadi 84 dengan nilai tertinggi adalah 100 dan nilai terendah adalah 0 , dan peserta didik yang tuntas KKM menjadi $83 \%$.

\section{UCAPAN TERIMA KASIH}

Penulis sekaligus peneliti mengucapkan puji syukur kepada Allah SWT atas limpahan Rahmat dan Ridho-Nya dalam proses penelitian ini. Peneliti mengucapkan terimakasih kepada keluargaku yaitu kedua orang tuaku Bapak Heri dan Ibu Sri Warsinah, kepada Suamiku Bapak Danang Dian Lukmana, kepada saudaraku Rochmad Ari dan Fauzani, serta anak-anaku Caca dan Rendra yang selalu memberikan dukungan secara moral dan materiil, dan Ibu Nani Mediatati, Bapak Widiyanto, Bu Anik Jarwati dan peserta didik kelas 3 SDN Bumireso yang telah membantu kami sehingga penulis dapat menyelesaikan penelitian ini. Semoga penelitian ini dapat bermanfaat bagi kita semua.

\section{REFERENSI}

Arikunto, Suharsimi (2010). Prosedur Penelitian: Suatu Pendekatan Praktik. Jakarta: Rineka Cipta.

(2011). Penelitian Tindakan Kelas. Jakarta: Bumi Aksara.

Hosnan, M. (2016). Pendekatan Saintifik dan Kontekstual dalam Pembelajaran Abad 21. Bogor: Ghalia Indonesia. 
Kepmendikbud. (2020). Kepmendikbud No 719/P/2020 Tentang Pedoman Pelaksanaan Kurikulum Pada Satuan Pendidikan Dalam Kondisi Khusus. Kemendikbud

Oktaviani, W., Kristin, F., \& Anugraheni, I. (2018). Penerapan model pembelajaran discovery learning untuk meningkatkan kemampuan berpikir kritis dan hasil belajar matematika siswa kelas 5 SD. Jurnal Basicedu, 2(2), 5-10.

Prasasti, D. E., Koeswanti, H. D., \& Giarti, S. (2019). Peningkatan keterampilan berpikir kritis dan hasil belajar matematika melalui model discovery learning di kelas IV SD. Jurnal Basicedu, 3(1), 174-179.

Purwanto (2013). Evaluasi Hasil Belajar. Yogyakarta: Pustaka Pelajar.

Supratiknya, A. (2012). Penilaian Hasil Belajar dengan Teknik Nontes. Yogyakarta:

Penerbit Universitas Sanata Dharma 